\title{
Testy oceniające celowość zastosowanych wzmocnień dźwięków w klasie i w domu - kwestionariusze ECLB i CHILD oraz możliwości ich zastosowania
}

\section{Tests assessing desirability of sound amplification used in the classroom and at home - ECLB and CHILD questionnaires and the possibility of their use}

\author{
Aleksandra Jordan ${ }^{1}$, Agnieszka Ptaszkowska ${ }^{1}$, Zdzisław M. Kurkowski $^{1,2}$ \\ ${ }^{1}$ Uniwersytet Marii Curie-Skłodowskiej, Zakład Logopedii i Językoznawstwa Stosowanego, Lublin \\ ${ }^{2}$ Instytut Fizjologii i Patologii Słuchu, Światowe Centrum Słuchu, Warszawa/Kajetany
}

Adres autora: Aleksandra Jordan, Uniwersytet Marii Curie-Skłodowskiej, Zakład Logopedii i Językoznawstwa Stosowanego, ul. Sowińskiego 17, 20-040 Lublin, e-mail: a.j.nycz@gmail.com

\section{Streszczenie}

W artykule przedstawiono opis dwóch testów: Evaluation of Classroom Listening Behaviors - ECLB i Children's Home Inventory of Listening Difficulty - CHILD. Ponadto niniejsza praca zawiera przegląd literatury pod kątem wykorzystania obu kwestionariuszy. Celem artykułu jest zapoznanie czytelnika z omawianymi testami oraz ukazanie ich przydatności.

Słowa kluczowe: Evaluation of Classroom Listening Behaviors • Children's Home Inventory of Listening Difficulty • warunki akustyczne w domu i szkole $\bullet$ ubytki słuchu • amplifikacje

\section{Abstract}

The article describes two tests: the Evaluation of Classroom Listening Behaviors - ECLB and the Children's Home Inventory of Listening Difficulty - CHILD. In addition, it provides an overview of foreign-language literature for using both questionnaires. The purpose of this article is to familiarize the reader with the tests and to demonstrate their usefulness.

Key words: Evaluation of Classroom Listening Behaviors • Children's Home Inventory of Listening Difficulty • acoustic conditions at home and school $\bullet$ hearing loss $\bullet$ amplification

\section{Wstęp}

Ubytek słuchu może pogorszyć jakość życia, codzienne funkcjonowanie zarówno dzieci, jak i ich rodzin. Trudno jest określić rzeczywisty stan percepcji słuchowej wyłącznie na podstawie audiogramu [1]. Zadaniem audiologów jest określenie faktycznego stanu narządu słuchu oraz możliwości słuchowych dziecka, w celu wyciągnięcia jak najbardziej obiektywnych i trafnych wniosków. Testy omawiane w niniejszym artykule pozwalają w szerszej perspektywie ocenić odbiór dźwięków przez dzieci w różnych sytuacjach akustycznych oraz pomóc w ujawnieniu potrzeb komunikacyjnych dzieci w środowisku szkolnym oraz domowym, czyli w miejscach, w których spędzają one większość czasu. Dodatkowym atutem opisywanych narzędzi jest możliwość ich wykorzystania jako pre-testów i post-testów, co pozwala monitorować uzyskiwane przez dzieci wyniki w nauce oraz umożliwia ocenę skuteczności prowadzonych działań rehabilitacyjnych.

Istnieje wiele kwestionariuszy będących podstawowymi narzędziami stosowanymi przez audiologów, nauczycieli i rodziców, które mogą być pomocne w określeniu odpowiednich form pomocy dla uczniów z ubytkiem słuchu.

W artykule przedstawiono opis dwóch testów: Evaluation of Classroom Listening Behaviors - ECLB [2] i Children's Home Inventory of Listening Difficulty - CHILD [3]. Pierwszy z nich może być wykorzystany przez nauczycieli do oceny skuteczności zastosowanych urządzeń wzmacniających dźwięki w klasie. Drugi kwestionariusz, wypełniany przez rodziców i dzieci, pozwala na ocenę umiejętności słuchowych dziecka w warunkach domowych. Testy ECLB i CHILD nie są wykorzystywane w naszym kraju, 
ponieważ do tej pory nie zostały zaadaptowane do polskich warunków. Zdaniem autorów niniejszego artykułu wprowadzenie obu kwestionariuszy ułatwiłoby kompleksową opiekę nad dziećmi z ubytkami słuchu, umożliwiając ocenę warunków akustycznych, jakie panują zarówno w domu, jak i w szkole - dwóch najważniejszych środowiskach dziecka w wieku szkolnym.

\section{Evaluation of Classroom Listening Behaviors (ECLB)}

Evaluation of Classroom Listening Behaviors (ECLB) to kwestionariusz opracowany w 1985 roku, a jego autorem jest J. VanDyke [2]. Jest to test przydatny w placówkach oświatowych do oceny efektów uzyskanych dzięki zastosowaniu osobistych urządzeń wspomagających słuchanie, takich jak aparaty słuchowe czy systemy FM, a przede wszystkim do oceny, czy zastosowane wzmocnienie daje poprawę umiejętności słuchania [4].

ECLB może służyć do oceny korzyści z modyfikacji ustawień urządzeń wzmacniających dźwięki. Kwestionariusz obejmuje 10 pozycji, które są oceniane w skali 5-stopniowej, gdzie 5 oznacza „często”, 3 oznacza „czasami”, a 1 oznacza „rzadko”. Maksymalny wynik to 50 . Większość pozycji jest sparowanych, np. słuchanie $\mathrm{z}$ bliska i z daleka, $\mathrm{z}$ jednego i z wielu kierunków, rozumienie mowy w kontakcie $\mathrm{z}$ jedną osobą i grupą [5].

\section{Children's Home Inventory of Listening Difficulty (CHILD)}

Children's Home Inventory of Listening Difficulty (CHILD) to test opracowany przez K. Anderson i J. Smaldino w 2000 roku [3]. Kwestionariusz może być wykorzystywany przez rodziców dzieci w wieku 3-12 lat oraz wypełniany przez dzieci powyżej 7 roku życia. Narzędzie przedstawia typowe domowe sytuacje w ciszy i hałasie, różnice w słyszeniu wynikające z różnej odległości od źródła dźwięku, a także zmiany akustyczne oceniane na innych płaszczyznach ważnych dla dziecka, takich jak kontakty rodzinne, komunikacja $\mathrm{z}$ rówieśnikami czy słuchanie $\mathrm{w}$ zatłoczonych miejscach [6]. Ośmiopunktowa skala służy do oceny u dziecka umiejętności słyszenia dźwięków otoczenia i mowy, rozpoznawania dźwięków i rozumienia mowy. Wyniki z testu CHILD mogą być wykorzystane do oceny efektywności zastosowanych urządzeń wzmacniających dźwięki oraz wskazania potrzeby korzystania z urządzeń wspomagających percepcję słuchową [6,7]. Dane uzyskane w teście CHILD mogą także dostarczać informacji o tym, jaka jest percepcja słuchowa dziecka $\mathrm{w}$ hałasie, a tym samym pozwalają zwrócić uwagę na potrzebę dbania o odpowiednią akustykę w klasie, umożliwiającą uczniom lepszy odbiór mowy w czasie lekcji [6]. Ponadto CHILD jest kwestionariuszem pozwalającym rodzicom wraz z dziećmi w środowisku domowym oraz nauczycielom w środowisku szkolnym ocenić funkcjonowanie dziecka $w$ różnych warunkach akustycznych, jak również obserwować efekty zastosowania urządzeń wzmacniających [8]. CHILD to narzędzie skupione na sytuacji domowej, napisane prostym, zrozumiałym językiem, a pytania w nim zawarte są odpowiednie do poziomu językowego ucznia. Ponadto test ten pozwala rozpoznać problemy słuchowe u dziecka w tych sytuacjach [6,9]. Jest to także czułe narzędzie umożliwiające wykrycie nieznacznych trudności ze słyszeniem występujących u dzieci z lekkim, okresowym niedosłuchem lub jednostronnym ubytkiem słuchu [6]. Może ponadto posłużyć rodzicom do wykrycia lub potwierdzenia problemów słuchowych ich dziecka. Autorzy kwestionariusza sugerują, żeby CHILD był wypełniany przez rodziców jeszcze przed wizytą u audiologa, na której odbywa się wstępna ocena słyszenia dziecka. Uzyskane w ten sposób przez specjalistę informacje mogą pomóc mu w postawieniu właściwej diagnozy, zaplanowaniu indywidualnej formy pomocy oraz jeśli to konieczne - doborze aparatów słuchowych. Ponadto wyniki testu mogą być przydatne podczas ustawiania urządzeń pomocniczych, takich jak alarmy czy wzmocnienia telefonów. CHILD może być również wykorzystywany do monitorowania nabywanych umiejętności słuchowych, będących efektem korzystania z protez słuchowych i prowadzonego treningu słuchowego [1].

Children's Home Inventory of Listening Difficulty posiada dwie wersje:

1. Children's Home Inventory for Listening Difficulties Family Member - Questions for the Family Member to Answer (wersja dla rodziców).

\section{Children's Home Inventory for Listening Difficulties}

- Questions for the Child to Answer (wersja dla dzieci).

\section{Children's Home Inventory for Listening Difficulties Family Member - Questions for the Family Member to Answer}

Zadaniem rodziców wypełniających test CHILD jest ocenienie możliwości percepcji słuchowej swojego dziecka oraz zaznaczenie odpowiedniego poziomu na skali [3]. Wypełnienie formularza pozwala zrozumieć zależność między ubytkiem słuchu dziecka a jego możliwościami słuchowymi w różnych warunkach, dzięki czemu w rodzinie wzrasta świadomość dotycząca ograniczeń słuchowych dziecka. Daje to punkt wyjścia do dyskusji na temat zmian, jakie należy wprowadzić w rodzinie, aby stworzyć takie warunki domowe, które bardziej sprzyjałyby efektywnemu słuchaniu. Ponadto informacje ujawnione w teście mogą pomóc rodzicom w zrozumieniu konsekwencji utraty słuchu, a w szczególności subtelnych zmian często wpływających na komunikowanie się dziecka, np. koncentracja uwagi, wykonywanie poleceń [1]. Przeprowadzenie testu CHILD zapewnia rodzinie wiedzę na temat trudności komunikacyjnych dziecka w codziennym życiu. Uświadamia opiekunom, że nawet przy dużych korzyściach z amplifikacji, za pomocą aparatów słuchowych i systemów FM, słuchanie nawet dla dzieci, które dobrze opanowały mowę i język, będzie stanowiło większe wyzwanie niż dla ich normalnie słyszących rówieśników. Test CHILD pomaga zwrócić uwagę na ewentualne trudności $\mathrm{w}$ funkcjonowaniu dziecka w szkole także tym rodzicom, którzy rozpoczęli rehabilitację dziecka już we wczesnym dzieciństwie i uważają język oraz mowę swoich dzieci za prawidłowe. Moment, w którym dziecko $\mathrm{z}$ wadą słuchu rozpoczyna naukę w szkole, wymaga bowiem szczególnej uważności ze strony opiekunów. Wiedza, jakiej dostarcza test CHILD, może im pomóc sprostać nowym wyzwaniom, a także ułatwić przedstawienie zespołowi szkolnemu potrzeb dziecka $\mathrm{z}$ wadą słuchu w zakresie odpowiedniego przystosowania klasy [6]. 


\section{Children's Home Inventory for Listening Difficulties - Questions for the Child to Answer}

Istnieje również wersja CHILD, którą może wypełnić starsze dziecko, oceniając wzmocnienia lub ułatwienia akustyczne stosowane przez rodziców w domu. Wiarygodność tego testu zależy od wieku dziecka, jego dojrzałości i zrozumienia swoich potrzeb. Kwestionariusz ten jest wiarygodny dopiero w przypadku dzieci, które osiągnęły minimalny wiek do przeprowadzenia samooceny, tj. 7-8 lat $[1,6]$. Zadaniem dziecka wypełniającego test jest wyobrażenie sobie siebie w różnych sytuacjach akustycznych. Dziecko $\mathrm{z}$ ubytkiem słuchu musi ocenić swoje słuchanie i rozumienie mowy na ośmiopunktowej skali. CHILD stanowi podstawę dla audiologa i rodziców do wprowadzenia nowych urządzeń wspomagających słuchanie, gdy dziecko zgłasza trudności np. w słuchaniu w hałasie czy podczas rozmów telefonicznych, aby mogło stać się bardziej niezależne [6]. Kwestionariusz CHILD może być wypełniany przez dziecko również w ramach post-testu - po okresie próbnego stosowania wzmocnienia dźwięków, aby ocenić funkcjonalne korzyści z używania nowych aparatów słuchowych w środowisku domowym [1]. Po wypełnieniu obu wersji testu można porównać odpowiedzi rodziców i dzieci, a także omówić kwestie związane z poczuciem własnej wartości dziecka, świadomością interakcji społecznych, dynamiką komunikacyjną i relacjami z rówieśnikami. Szczegółowe informacje na temat ograniczeń słuchowych dziecka w różnych warunkach środowiskowych, dostarczane przez test, mogą wesprzeć zespół szkolny w procesie przystosowywania klasy do indywidualnych potrzeb danego dziecka, tak aby zapewnić mu równy dostęp do instrukcji słownych i komunikacji werbalnej z rówieśnikami [6].

\section{Wykorzystanie testów ECLB i CHILD}

Kwestionariusze Evaluation of Classroom Listening Behaviors oraz Children's Home Inventory for Listening Difficulties są najczęściej wykorzystywane do oceny poprawy umiejętności słuchowych po zastosowaniu wzmocnień takich jak aparaty słuchowe lub systemy FM.

N. DiSarno, M. Schowalter i P. Grassa [10] postawili hipotezę, iż nauczyciele, którzy zgadzają się na zastosowanie wzmocnienia akustycznego w klasie, mogą być z góry przekonani o jego skuteczności. Może to mieć wpływ na sposób, w jaki oceniają zmiany po zastosowaniu urządzeń wzmacniających. Dlatego autorzy przeprowadzili badanie, w którym do oceny wzmocnienia zastosowanego w klasie zatrudniono dwóch ekspertów (nauczyciela znającego dane środowisko i drugiego niezależnego). Zadaniem każdej osoby było określenie, czy w danej klasie obserwuje się poprawę umiejętności słuchowych dzieci, a jeśli tak, to $\mathrm{w}$ jakim stopniu i zakresie.

Podczas badania przeprowadzonego w grupie uczniów $\mathrm{z}$ trudnościami w uczeniu się przez trzy miesiące stosowano system Phonic Ear FM. Umiejętności słuchowe dzieci i ich zachowania szkolne były niezależnie oceniane przez nauczycieli w klasie za pomoca Listening and Learning Observation - LLO oraz Evaluation of Classroom Listening Behaviors - ECLB [2]. Nauczyciele wypełniali kwestionariusze przed zastosowaniem systemu FM oraz ponownie - po sześciu tygodniach stosowania urządzeń, a następnie na zakończenie projektu (po dwunastu tygodniach).

Autorzy opisywanego artykułu wskazują, iż główną zaletą zastosowania wzmocnienia dźwięków w klasie był wzrost uwagi uczniów i utrzymywanie się jej na ustalonym poziomie, odnotowano również spadek zmęczenia nauczycieli. Uczniowie chętnie korzystali z systemu FM. Wielu nauczycieli przyznało, że wzmocnienia w klasie mogą być przydatne w różnych warunkach - w klasach ogólnodostępnych, klasach dla uczniów z uszkodzonym narządem słuchu czy też w klasach dla osób z trudnościami w nauce. Korzystanie ze wzmocnienia w szkole może być prostym i tanim sposobem na poprawę możliwości uczenia się u wielu uczniów.

Badanie wykazało także, że zatrudnienie dwóch niezależnych ekspertów może być korzystną metodą do oceny umiejętności słuchowych. Dwóch oceniających nadaje wiarygodność uzyskanym wynikom, gdyż nawet jeśli nie zgadzają się ich oceny co do poziomu wyjściowego przed zastosowaniem wzmocnienia, to następuje zgodność ocen dotyczących poprawy umiejętności słuchowych uczniów po zastosowaniu systemów FM.

W 2002 roku H.A.S.S. Communications (firma z siedziba w Pretorii, RPA) przeprowadziła pilotażowy projekt, który polegał na zastosowaniu wzmocnienia w klasach po to, aby zbadać jego wpływ na słuchanie, uczenie się oraz zachowanie uczniów ze szkół ogólnodostępnych [11]. W projekcie wzięło udział 95 uczniów szkół podstawowych i 72 uczniów szkół średnich z Gauteng (RPA). Dwie szkoły znajdowały się w spokojnej okolicy, kolejne dwie były położone na skrzyżowaniu ruchliwych ulic, a jedna ze szkół znajdowała się w pobliżu lotniska. W badaniach zastosowano system dźwięku PhonicEar RADIUM - umożliwiający wzmocnienie mowy większe o $8-10 \mathrm{~dB}$ niż hałas panujący w klasie. Urządzenia te przetestowano w szkołach, w których sale lekcyjne miały niekorzystne warunki akustyczne.

Opisywany projekt miał na celu określenie, czy umiejętności słuchowe i szkolne uczniów poprawią się po zastosowaniu wzmocnienia dźwięków. Autorzy wyszli z założenia, że możliwości słuchania i uczenia się dzieci są często ograniczone, gdy warunki akustyczne panujące w klasie nie są optymalne. Do oceny umiejętności słuchowych dzieci wykorzystano kwestionariusz Listening and Learning $\mathrm{Ob}$ servation - LLO oraz test Evaluation of Classroom Listening Behaviours - ECLB [2]. Kwestionariusze były wypełniane w różnych momentach realizacji projektu - najpierw jako wstępna ocena (przed zastosowaniem wzmocnień), następnie po 3-5 tygodniach trwania badań i później jako ocena końcowa (po 6-10 tygodniach).

Po 6-10 tygodniach stosowania wzmocnień odnotowano ogólną poprawę w słuchaniu i umiejętnościach edukacyjnych uczniów o 13,5\% (LLO) i 11,75\% (ECLB).

Wyniki tego projektu pokazały, że u dzieci uczących się w klasach, w których zastosowano wzmocnienia dźwięków, obserwuje się większe i szybsze zmiany w zakresie zachowań słuchowych, edukacyjnych oraz umiejętności uczenia się. Poprawa była widoczna przede wszystkim u uczniów ze szkół podstawowych. 
Uczniowie pozytywnie ocenili wprowadzone wzmocnienia. Ponad $90 \%$ z nich zgodziło się, iż system FM pomógł im lepiej słyszeć nauczyciela, a 97\% badanych stwierdziło, iż głos nauczyciela stał się głośniejszy i wyraźniejszy. Uczniowie wyrazili chęć korzystania z systemu FM w następnym roku szkolnym [11].

W latach 1993-1995 zrealizowano projekt ICA - Improving Classroom Acoustics w celu określenia, czy umiejętności słuchowe oraz uczenie się dzieci mogą poprawić się w wyniku zastosowania w klasie urządzeń wzmacniających, poprawiających warunki percepcji słuchowej $[12,13]$.

W latach 1993-1994 zrealizowano projekt pilotażowy, a w roku 1994 oraz w latach 1994-1995 przeprowadzono kolejne dwa projekty stanowiące kontynuację badań pilotażowych.

W projekcie z 1994 roku został wykorzystany kwestionariusz Evaluation of Classroom Listening Behaviors - ECLB [2] jako dodatkowy instrument służący do obserwacji uczniów. Ponadto na potrzeby projektu autorzy stworzyli test Listening and Learning Observation - LLO [12].

W pierwszej fazie projektu (1993-1994) wzięło udział 4855 uczniów (20 grup eksperymentalnych oraz 20 grup kontrolnych) obserwowanych przez 12 tygodni. Podczas kontynuacji projektu w 1994 roku przez 12 tygodni badano grupę 1319 uczniów zebranych w 30 grup eksperymentalnych i tyle samo grup kontrolnych. Przez 30 tygodni obserwowano z kolei grupę 804 uczniów (po 20 grup eksperymentalnych i kontrolnych). W trwającej 4 tygodnie kolejnej fazie projektu realizowanej w latach 1994-1995 wzięło udział 431 uczniów z 34 klas [13].

Wyniki uzyskane w teście ECLB pokryły się z danymi zebranymi za pomocą kwestionariusza LLO.

Z przeprowadzonych badań wynika, że korelacja między wynikami testów LLO i ECLB jest bardzo silna $(0,788-$ $0,837)$. Takie wyniki wskazują, że są to wrażliwe narzędzia do oceny umiejętności słuchowych.

Lepsze rezultaty stosowanych urządzeń wzmacniających zaobserwowano u młodszych dzieci. C. Crandell i wsp. [14] sugerują, że może to być spowodowane częstszym występowaniem u tej grupy dzieci zapaleń ucha środkowego, wpływających na pogorszenie słyszenia [13]. Ponadto stwierdzono, iż uczniowie w klasach, w których stosowano urządzenia wzmacniające, wykazują większe i zachodzące w szybszym tempie zmiany w zakresie umiejętności słuchowych i uczenia się niż osoby z grupy kontrolnej [12].

Dane zebrane dzięki testowi Evaluation of Classroom Listening Behaviors (ECLB) zostały również wykorzystane w badaniach wykonanych przez Miami-Data Country $\mathrm{Pu}-$ blic School w 2008 roku [15]. Autor badań zwraca uwagę na to, że stosowanie wzmocnienia nie tylko poprawia funkcjonowanie $\mathrm{w}$ klasie uczniów z problemami słuchowymi, lecz także może być przydatne dla uczniów ze słuchem prawidłowym. Uzasadnieniem tej tezy jest fakt, iż od tego, jak dzieci słyszą swojego nauczyciela, zależy to, jakie osiągają wyniki w nauce $[16,17]$. Ch. Blazer [15] opiera swoje badania na projekcie Improving Classroom Acoustics (ICA). Na podstawie wniosków płynących $\mathrm{z}$ wyników testów Listening and Learning Observation Form - LLO oraz Evaluation of Classroom Listening Behaviors - ECLB wykazał on, iż w klasach, w których stosuje się urządzenia wzmacniające, występuje znacznie większa zmiana umiejętności słuchowych u uczniów [13].

Badania Ch. Blazer [15] wykazały, że uczniowie z prawidłowym słuchem mogą z powodzeniem korzystać z systemów wzmacniających dźwięki w klasie. Zastosowane wzmocnienia pozwalają nauczycielom kontrolować i modyfikować wypowiedzi tak, aby ich głosy stały się wyraźniejsze, bardziej słyszalne na tle hałasu we wszystkich miejscach w klasie.

R. Condie i J. Tchorz w 2004 roku [18] w swoich badaniach wykorzystali test CHILD w celu oceny korzyści płynących z używania przez dzieci aparatów słuchowych Phonak Supero 412 BTE. W projekcie wzięło udział 10 dzieci (średnia wieku wynosiła 10,7 lat), ze zdiagnozowanym dwustronnym niedosłuchem odbiorczym, od stopnia umiarkowanego po głęboki. Przed przystąpieniem do badania dzieci korzystały obustronnie $z$ aparatów zausznych. Dwoje $\mathrm{z}$ nich posiadało aparat analogowy, pozostałe korzystały z urządzeń cyfrowych. Grupa badana została zebrana $\mathrm{z}$ różnych szkół w stanie Utah (Stany Zjednoczone). Dzieci otrzymały aparaty Phonak Supero 412 BTE z osobistymi wkładkami usznymi. W aparatach ustawiono dwa programy: spokojne oraz hałaśliwe warunki akustyczne. Po pewnym czasie użytkowania aparatów przeprowadzono badania, w których wykorzystano między innymi test CHILD, aby ocenić korzyści z eksperymentalnych urządzeń w porównaniu z korzyściami $\mathrm{z}$ aparatów słuchowych używanych przez dzieci wcześniej. Kwestionariusz CHILD wypełniło $8 \mathrm{z} 10$ badanych dzieci oraz rodzice wszystkich dzieci z grupy badanej. Wyniki wskazały na poprawę słyszenia w codziennych sytuacjach. Co ciekawe, średnie oceny dzieci były bardziej pozytywne niż opinie rodziców.

W artykule S. McKay z 2014 roku [19] poruszono problem wpływu jednostronnego ubytku słuchu u dzieci na ich funkcjonowanie w szkole i życiu społecznym. Badacze F. H. Bess i wsp. [20] oraz R. F. Oyler i wsp. [21] potwierdzają występowanie u dzieci z jednostronną głuchotą dużego problemu - głównie w zakresie lokalizacji dźwięku, a także rozumienia mowy w hałaśliwym otoczeniu. W 2002 roku w The Audiology Department at the Children's Hospital w Filadelfii zrealizowano projekt, w którym 28 dzieci z jednostronnym ubytkiem słuchu otrzymało na trzy miesiące odpowiednie aparaty słuchowe. Wiek dzieci z grupy badanej wahał się od 2 do 17 lat, a ubytki słuchu od stopnia lekkiego do umiarkowanie znacznego. Badanie miało na celu sprawdzenie, czy aparaty słuchowe poprawią funkcjonowanie dzieci w codziennych sytuacjach. W badaniu wykorzystano test CHILD, który wypełnili rodzice dzieci oraz sami badani, jeżeli byli w odpowiednim wieku. Większość wypełniających test stwierdziła, iż zauważa znaczną poprawę we wszystkich badanych dziedzinach. Dzieci zaakceptowały nowe aparaty słuchowe i zauważyły duże korzyści płynące $\mathrm{z}$ ich noszenia. Rodzice zgodnie stwierdzili, iż decyzja o zaopatrzeniu dzieci w aparaty słuchowe była słuszna i w wielu przypadkach mogła być podjęta znacznie wcześniej. 
Celem badania przeprowadzonego przez L. Briggs, L. Davidson i J. E. C. Lieu [22] było zbadanie, czy dzieci z jednostronnym ubytkiem słuchu odnoszą korzyści z używania tradycyjnego aparatu słuchowego w gorzej słyszącym uchu. W badaniu wzięło udział ośmioro dzieci w wieku od 7 do 12 lat $\mathrm{z}$ łagodnym do umiarkowanie ciężkiego jednostronnym ubytkiem słuchu oraz ich rodzice i nauczyciele. Dzieciom dopasowano cyfrowe aparaty słuchowe, zgodnie z pediatrycznymi i normatywnymi wymogami. Przed założeniem aparatu słuchowego i po trzech miesiącach korzystania $\mathrm{z}$ niego przeprowadzono testy oceniające percepcję mowy w ciszy i hałasie oraz zebrano subiektywne oceny uczestników badania (w tym za pomocą testu CHILD). Średnie wyniki percepcji mowy odnotowane w badanej grupie wykazały brak znaczących korzyści lub pogorszenia w każdorazowych badanych warunkach. Jednakże subiektywne oceny potwierdziły duże korzyści, zarówno w domu, jak i w szkole, płynące z użytkowania urządzeń wspomagających słyszenie. Efekty te były zauważane zarówno przez dzieci, jak i rodziców. W teście CHILD wykonanym po zastosowaniu wzmocnień uzyskano znacząco wyższy średni wynik. Odnotowano również istotnie lepsze klinicznie wyniki post-testu pomimo rzadszego używania aparatów słuchowych w domu i w weekendy niż w szkole. Zastosowane aparaty słuchowe przyniosły zatem korzyści i były dobrze odebrane przez uczestników badania.

T. Schmidtke-Flynn, M. Flynn oraz M. Harvey [23,24] w szkołach w Wielkiej Brytanii przeprowadzili badanie, w którym wzięło udział 11 uczniów w wieku od 5 do 15 lat, z ubytkami słuchu typu odbiorczego wahającymi się od stopnia umiarkowanego do głębokiego. Były to dzieci posługujące się mową. Percepcja i ekspresja mowy oraz poziom słownictwa zostały ocenione przed próbnym okresem zastosowania systemu FM. Wszyscy uczniowie korzystali z aparatów słuchowych na obojgu uszach przez co najmniej sześć miesięcy.

Autorzy opisywanego artykułu próbowali odpowiedzieć na następujące pytania:

1. Czy osobisty system FM w klasie poprawia rozumienie mowy u uczniów w porównaniu ze stosowaniem jedynie aparatów?

2. Jakie korzyści ze stosowania osobistego systemu FM w szkole i w domu dostrzegają dzieci, rodziny i nauczyciele?

Korzyści wypływające $\mathrm{z}$ amplifikacji zostały ocenione subiektywnie i obiektywnie za pomocą testu Neale Analysis of Reading Ability-Revised, NARA II i kwestionariuszy: Children's Home Inventory for Listening Difficulties - CHILD [3] oraz Children's Outcome Worksheet - COW [25]. Uczniowie wypełniali testy z pomocą rodziców lub nauczycieli. Każdy kwestionariusz został wypełniony przed rozpoczęciem stosowania systemu FM i po trzech miesiącach korzystania $\mathrm{z}$ niego. Pierwszy kwestionariusz koncentruje się na korzyściach płynących z używania aparatów słuchowych, drugi natomiast skupia się na zaletach połączenia systemu FM i aparatów słuchowych. Wynik testu CHILD prowadzi do identyfikacji obszarów, w których troska o dziecko i jego zdolności rozumienia mowy w określonych sytuacjach muszą być największe, a ponadto wskazuje na zyski, jakie przynosi dziecku korzystanie z dodatkowego wzmocnienia. Wyniki kwestionariusza wykazały korzyści z używania systemu FM w środowisku domowym. Porównanie średnich wyników uzyskanych w testach wypełnianych przez dzieci było istotne statystycznie $(\mathrm{t}=-2,43$, $\mathrm{df}=10, \mathrm{p}<0,05)$. Odchylenie standardowe wynosiło 0,3 w przypadku zastosowania jedynie aparatów słuchowych i 0,5 w przypadku połączenia systemu FM i aparatów słuchowych. Porównanie średnich wyników uzyskanych w testach wypełnianych przez rodziców również okazało się istotne statystycznie $(\mathrm{t}=-2,48, \mathrm{df}=10, \mathrm{p}<0,05)$ i wykazało korzyści z wykorzystania systemu FM. Odchylenie standardowe wynosiło 0,4 wyłącznie dla aparatów słuchowych, jak i połączenia systemu FM i aparatów słuchowych. Odpowiedzi zebrane od dzieci, rodziców i nauczycieli w teście CHILD potwierdziły znaczne korzyści z używania systemu FM. Główną zaletą, w porównaniu z używaniem jedynie aparatów słuchowych, był wzrost rozumienia mowy przez dzieci, spostrzegany zarówno przez nie, jak i ich rodziców oraz nauczycieli. CHILD wykazał korzyści z używania systemu FM także poza klasą - zapewnienie dzieciom lepszego rozumienia mowy w warunkach domowych. Połączenie osobistych systemów FM z aparatem słuchowym daje dzieciom $\mathrm{z}$ zaburzeniami słuchu optymalny dostęp do sygnału mowy.

Badanie przeprowadzone przez K. Condie, S. D. Scollie, P. C. Checkley [26] zestawia wyniki uzyskane u dzieci korzystających z osobistych analogowych aparatów słuchowych z wynikami uzyskanymi przez nie podczas korzystania z cyfrowych, dwumikrofonowych aparatów słuchowych ustawionych metodą DSL. Celem badania było ustalenie, czy zaawansowany cyfrowy aparat słuchowy może być pomyślnie dopasowany u dzieci oraz $\mathrm{w}$ jakim stopniu skorzystają one $\mathrm{z}$ nowych urządzeń $\mathrm{w}$ porównaniu $\mathrm{z}$ ich własnymi analogowymi aparatami słuchowymi. W badaniu wzięło udział dziesięcioro dzieci w wieku od 5 do 14 lat. U wszystkich dzieci zdiagnozowano wcześniej dwustronny odbiorczy ubytek słuchu, począwszy od umiarkowanego do znacznego (45-85 dB w lepszym uchu). Przed badaniem wszystkie dzieci nosiły dwa analogowe, jednokanałowe aparaty zauszne. Dzieci były rekrutowane z różnych szkół publicznych w Utah (RPA). Uczniowie byli posiadaczami osobistych liniowych, analogowych aparatów słuchowych, dobranych przez różnych audiologów. W czasie eksperymentu posługiwano się aparatami słuchowymi Phonak Claro 211 oraz 311 dAZ BTE z osobistymi wkładkami usznymi. Aby ocenić subiektywne różnice, zastosowano kwestionariusz CHILD, który został wykorzystany do pomiaru rzeczywistych parametrów słuchania $\mathrm{w}$ analogowych aparatach słuchowych i w eksperymentalnych aparatach cyfrowych. Piętnaście pytań było ocenianych na skali od 0 do 8 punktów, gdzie wyższa nota wskazywała na lepszą ocenę słuchania. Średnie wyniki testu CHILD wzrosły z 4,8 do 6,5 dla dzieci i z 4,5 do 5,9 dla ich rodziców po okresie próbnym trwającym miesiąc. Ta zmiana była istotna statystycznie $(\mathrm{F}[1,7]=10,8, \mathrm{p}<0,05)$ dla wyników obojga rodziców $(\mathrm{t}[9]=-3,56, \mathrm{p}<0,05)$ i wyników dla dzieci $(\mathrm{t}[7]=3,78, \mathrm{p}<0,05)$. Porównując wyniki pre-testu i post-testu, można zauważyć, iż 50\% dzieci i $80 \%$ rodziców wskazało na znacznie większe korzyści w słuchaniu w czasie używania urządzeń cyfrowych. Wyniki te pokazują, że systematyczne stosowanie procedury „wybierz i zweryfikuj częstotliwość” może przyczynić się do poprawy rozumienia mowy w ciszy. W przypadku hałasu nie ma wątpliwości, że zastosowanie w aparacie 
dwóch mikrofonów jest głównym czynnikiem poprawiającym rozumienie mowy. Obiektywne pomiary wykazały, że podczas korzystania przez dzieci z cyfrowych, dwumikrofonowych aparatów słuchowych nastąpiła znaczna poprawa percepcji mowy w ciszy i hałasie w porównaniu z analogowymi aparatami słuchowymi. Subiektywnie również cyfrowe aparaty słuchowe były wyraźnie preferowane zarówno przez dzieci, jak i ich rodziców.

\section{Podsumowanie}

Wczesne wykrycie zaburzeń słuchu umożliwia szybkie wyposażenie dziecka w aparaty słuchowe i rozpoczęcie wychowania słuchowego. Testy ECLB i CHILD pozwalają rozpoznać zaburzenia słuchu i zapobiec ich negatywnym konsekwencjom. Takie działanie ma ogromne znaczenie dla rozwoju mowy i języka oraz rozwoju emocjonalnego i poznawczego dziecka. Kluczem do poprawy umiejętności językowych jest optymalna i spójna ocena komunikacji, której można dokonać za pomocą omawianych testów. Należy także pamiętać, że hałas w otoczeniu może wpływać na rozumienie mowy, wyniki w nauce, umiejętność czytania i pisania, koncentrację, uwagę i zachowanie wszystkich dzieci niezależnie od tego, czy mają prawidłowy słuch czy niedosłuch $[27,28]$. Korzystanie z osobistych urządzeń wzmacniających jest sposobem na to, aby wzmocnić głos nauczyciela, zwiększyć SNR i poprawić akustykę klasy. Dzieci przez 75\% czasu w ciągu dnia znajdują się w sytuacjach wymagających aktywnego słuchania. W związ$\mathrm{ku} \mathrm{z}$ tym do nauki i prawidłowego rozwoju potrzebują optymalnego dostępu do sygnału mowy w klasach szkolnych. Słuchanie jest podstawowym elementem edukacji dzieci, od których wymagane jest, aby słuchały i rozumiały to, co jest przekazywane przez nauczyciela [1].

Autorzy niniejszego artykułu uważają, iż testy ECLB i CHILD powinny zostać zaadaptowane do polskich realiów, gdyż stanowią skuteczne narzędzia do oceny percepcji słuchowej dziecka. Równoczesne zastosowanie obu testów pozwala na wykrycie nierozpoznanych problemów i kompleksową diagnozę. Testy te w jednakowym stopniu angażując rodzinę i szkołę, mogą przyczynić się do współpracy rodziców i nauczycieli, co stworzy możliwość wypracowania wspólnych działań terapeutycznych. Ciekawe może być również porównanie percepcji i postrzegania dziecka przez rodzica i nauczyciela z tym, jak dziecko widzi samego siebie i jak radzi sobie w różnych warunkach słuchowych. Dzięki temu dziecko i jego problemy ze słyszeniem zostaną zauważone zarówno w szkole, jak i w domu, a jego potrzeby w zakresie poprawy percepcji dźwięków będą lepiej zaspokojone. Opisywane testy mogą bowiem pomóc ocenić warunki percepcyjne, stosowane wzmocnienie i tym samym nakreślić właściwe sposoby postępowania.

Artykut powstat $w$ związu $z$ realizacja projektu "Zintegrowany system narzędzi do diagnostyki i telerehabilitacji schorzeń narzadów zmysłów (słuchu, wzroku, mowy, równowagi, smaku, powonienia)" wspótfinansowanego przez Narodowe Centrum Badań i Rozwoju w ramach Programu STRATEGMED".

\section{Piśmiennictwo:}

1. Anderson K, Smaldino J. CHILD - Children's Home Inventory for Listening Difficulties (Used with children age 3-12 years). Design by Oticon 2007; 2000.

2. VanDyke J. Evaluation of Classroom Listening Behaviors (ECLB). Rocky Mountain Journal of Communication Disorders, 1985; 1: 7-9.

3. Anderson K, Smaldino J. Children's Home Inventory for Listening Difficulties - CHILD. Rationale and Applications. Design by Phonak; 2000.

4. Johnson Ch, Seaton J. Educational Audiology Handbook. Second Edition; 2012.

5. Lawson G. Peterson M. Speech audiometry. A volume in the core clinical concepts in audiology series; 2011.

6. Anderson K. Parent involvement: The magic ingredient in successful child outcomes. Hearing Review, 2002; 9(11): 24-56.

7. Valente M, Hosford-Dunn H, Roeser RJ. Audiology: Treatment. Thieme Publishers Series; 2008.

8. Madell JR, Flexer CA. Pediatric audiology: diagnosis, technology, and management. Thieme Publishers Series; 2008.

9. Parthasarathy TK. An introduction to auditory processing disorders in children; 2014.

10. DiSarno N, Schowalter M, Grassa P. Classroom amplification to enhance student performance. Teaching Exceptional Children, 2002; 34(6): 20-6.

11. Pilot Project. Classroom amplification. Final statistical report; 2002, http://www.phonicear.com/ /media/Downloads/SF/Articles_studies_references/Pilot_Project_Report_SouthAfrica_classroom-amplification.ashx

12. Florida Department of Education Improving Classroom Acoustic: Inservice training manual. Tallahassee. FL; 1995.
13. Rosenberg G, Blake-Rahter P, Heavner J, Allen L, Redmond B, Phillips J i wsp. Improving Classroom Acoustic (ICA): A Three-Year FM sound filed classroom amplification study. Journal of Educational Audiology, 1999; 7: 7-28.

14. Crandell C, Smaldino J, Flexer C. Soundfield FM amplification: Theory and practical applications. San Diego: Singular Publishing Group, Inc.; 1995.

15. Blazer Ch. Improving the classroom environment: classroom amplification systems. Information Capsule Research Services, 2007; 0607: 1-11.

16. Cole W. Now hear this. Time Magazine; 2006.

17. Ross M, Levitt H. Classroom Sound-Field Systems. Rehabilitation Engineering Research Center on Hearing Enhancement; 2002, http://www.hearingresearch.org/Dr.Ross/classroom_sound_field_systems.htm.

18. Condie R, Tchorz J. High-power hearing aids and children. Audiology Online. Phonak. March; 2004, http://www.audiologyonline.com/articles/high-power-hearing-aids-and-1096.

19. McKay S. To aid or not to aid: children with unilateral hearing loss. Healthy Hearing Magazine. Hands \& Voices; 2014, http:// www.handsandvoices.org/articles/tech/To_AidorNot_toAid.html.

20. Bess FH, Tharpe AM. Unilateral hearing impairment in children. Pediatrics, 1984; 74: 206-16.

21. Oyler RF, Oyler AL, Matkin ND. Unilateral hearing loss: Demographics and educational impact. Language Speech Hearing Services Schools, 1988; 19: 201-10.

22. Briggs L, Davidson L, Lieu JEC. Outcomes of conventional amplification for pediatric unilateral hearing loss. Ann Otol Rhinol Laryngol, 2011; 120(7): 448-54. 
23. Schmidtke-Flynn T, Flynn M, Gregory M. The FM advantage in the real classroom. Journal of Educational Audiology, 2005; 12: $37-44$

24. Schmidtke-Flynn T, Flynn M, Harvey M. The FM advantage in the real classroom. Audiological research documentation. News from Oticon; 2004, www.oticon.com.

25. Williams C. The Children's Outcome Worksheet (COW) - an Outcome measure focusing on children's needs (Ages 4-12). News from Oticon; 2003, www.oticon.com.
26. Condie RK, Scollie SD, Checkley PC. Children's performance: analog vs digital adaptive dual-microphone instruments; 2002, http://www.hearingreview.com/2002/06/childrens-performanceanalog-vs-digital-adaptive-dual-microphone-instruments.

27. Crandell CC, Smaldino J. Classroom acoustics for children with normal hearing and with hearing impairment. Language, Speech, and Hearing Services in Schools, 2000; 31: 362-70.

28. Flexer C. Individual and sound-field FM systems: rationale, description, and use. Volta Review, 1997; 99(3): 133-62. 